\title{
The Empowerment of the Community as a Learning Source for Junior High School
}

\author{
I Wayan Kertih*, Wayan Mahardika Prasetya Wiratama \\ Prodi S2 PIPS \\ Undiksha \\ Bali, Indonesia \\ *wayan.kertih@undiksha.ac.id
}

\begin{abstract}
This study aims at identifying, mapping, and analyzing the teachers' insights and abilities in teaching development with a dimension of empowerment important elements in community life as learning resources for social sciences. We applied the bibliography research approach (literature study and ethnography) and social studies practice in Junior High School of Undiksha Laboratory. The results of the first year showed that various important elements in the community life could be used and developed as learning resources in Social Studies teaching at SMP/MTs, and the teachers' lack ability in teaching development dimensioning of the empowerment important elements in the community life as learning resources. Therefore, to make social studies learning became powerful, it was necessary to empower the important elements of people's lives in developing materials and selecting social studies learning resources at the junior high school level.
\end{abstract}

Keywords—social studies teaching, community as learning resources

\section{INTRODUCTION}

Social studies subject is an application-oriented educational program, developing thinking skills, learning abilities, curiosity, and developing a caring and responsible attitude towards the social environment. It means that the education in its efforts to shape behavior, impart knowledge, thought processes, values, learning methods, cognitive skills and social essential, and truth values will also be determined by how the community views the world and its values (society's prevailing world view and values) [1-3].

Unfortunately, until the present, social studies learning are still faced with the problem of not optimally empowering the community and life in the school environment as a learning resource. Textbooks are still the only source and teaching material used by teachers to teach social studies. Research in Sukadi and Muchtar [2,4] revealed that the approach used in material development is still dominant for mastery of concepts, events, and generalizations of scientific fields. These are certainly not appropriate with the objectives of social studies education to produce humans who can think globally, act locally, respect and commit to the nationally [5-7]. To realize the nature and objectives of such social studies education, accordingly social studies learning needs to be developed powerfully. The powerful social studies learning that is meant in this case are challenging, meaningful, value-based, and integrated. For social studies learning to be powerful, community empowerment as a learning resource needs to be done by teachers.

Community empowerment as a learning resource is appropriate with the objectives of social studies learning as a social education program aiming to provide knowledge, values and attitudes, and social skills to students directly, actually, and human interests in their lives in society [5]. The results of research that have been conducted by Kertih [8] revealed that the life of the community and the environment around the school can be used as a learning resource or as a field of study in social studies learning. Research conducted by Kertih [8] can prove that the use of the community environment as a learning resource can develop affection values that lead to the socio-economic and cultural aspects of the surrounding community.

The results of these studies suggest that the use of the environment and background of community life as a source of learning directs the process and student learning outcomes on aspects related to community life, and various aspects of the interests associated with it $[5,6]$. Due to the limited development of ideas as this research thus, this research is very important to be conducted. This research is expected to develop the substance of social science learning studies that integrates the concepts of local culture and the empowerment of important elements of community life as media and social studies learning resources. For this reason, this research is important to be conducted.

\section{METHODS}

This research applied bibliographical research (literature study) to find philosophies and theories about the curriculum. Pre-survey research as a need assessment of students and teachers of SMP Lab. Undiksha in social studies learning, including identification of learning resources, facilities, and a social science learning environment used as a basis for 
developing a social science learning model (prototype model) is appropriate for the Curriculum 2013. Materials reviewed and used as the basis for model development are all dimensions of social studies learning in SMP/MTs which consist of curriculum, textbooks, learning models, learning resources, learning facilities and infrastructure, and the carrying capacity of the learning environment.

The main data collection techniques applied in this study was document study, in-depth interviews, and observation. The data collection instruments applied in the first phase of research consisted of several instruments, namely recording, interviewing, and observing. The data collected in this study were qualitative. Based on this, for the sake of data processing, the data were analyzed qualitatively using verbatim analysis techniques to give meaning to data descriptions concerning the content, logic of inference, processes, and products (outputs) of this study $[4,7]$.

\section{RESULTS AND DISCUSSION}

\section{A. Results}

1) Overview of social studies learning in SMP Lab. Undiksha: Based on the results of observations on the practice of social studies learning in SMP Lab. Undiksha, this research concluded that social studies learning by teachers were lacking, even if it could be said that it did not reflect its realization as an educational program that empowers the community as a source of learning. This could be seen in the development of the material, in the learning process, as well as in the assessment process. For instance, it could be shown from the weaknesses of the teachers were when the teachers explained about social interactions, for instance, what should be taught not only concepts and facts but should also explain the values that exist behind the historical facts, supported by real examples that are sourced from the surrounding environment.

In connection with the development of material social skills that should have been developed in the Social Studies Education program, in reality, it is still not optimal. This happens because the teachers' efforts to empower the important elements of community life and the use of symbols as media and learning resources in social studies learning has not been optimal. Various important elements of community life are available in schools and the environment around the school which can be used as learning media and training social skills for students.

Concerning the learning carried out, it appears that it has not shown the principles of learning that strive for students to recognize and accept cultural values and national character as their own, and to be responsible for the decisions they make through the stages of recognizing choices, assessing choices, determining stances, and then make an appropriate value for self-confidence. The learning that has been developed also has not shown any effort to make the students learn through a process of thinking, behaving, and acting. These three processes do not appear to be carried out by the teachers. This process is important to do to develop the ability of students to carry out social activities and encourage students to notice themselves as social beings.

The thing that seems to be not optimal in social studies learning by teachers is related to assessment. In terms of assessment, what teachers do is limited to only relying on assessments in the form of tests. Social studies education will be effective by the vision, mission, and objectives if the implementation of the assessment process and student learning outcomes is more authentic. For this, the assessment of students' learning processes and outcomes must be intact, comprehensive, authentic, meaningful, honest, transparent, objective, integrated, educating, empowering, and not judgmental. The use of assessment strategies utilizing interviews, observations, essay writing tests, performance tests, self-assessments, and portfolios are the main requirements for achieving social studies learning objectives.

2) The ability of teachers in developing learning through community empowerment as a source of social studies learning: Based on the results of data analysis, this study found that various important elements of community life that could be empowered as social studies learning resources have not been optimally empowered. The various important elements of community life have not been fully, comprehensively, and meaningfully empowered. The existence of various social, cultural, religious, political, and governmental and economic institutions with their respective functions and value orientations at any time influences the thinking, attitude, and acting patterns of all components of the school community. It was said because, students could directly construct and develop social, cultural, and religious values in real social life practices in the environment surrounding the existence of the school, as well as develops the social skills needed by students in the life of the community, nation, and state. This is what is called school education based on realworld experiences of children.

According to the principal's admission, accommodation to various interests and expectations of the community is important so that schools can follow the dynamics of changes and developments that occur in society as a basis for formulating the vision, mission, goals, and school education programs, including of course Social Studies Education and Learning. Here students can learn the profiles and characters of community leaders, temple leaders, religious leaders, police, soldiers, government officials about how they become role models for the community; how people interact and communicate; learn about the societal traditions called sima, dresta, and awig-awig; learn to organize and prepare for religious ceremonies; learn about ceremonial devices and paraphernalia with all their complexity and accuracy; learn about the patterns of social relations in the traditional village community; learn about social relations and etcetera. 
Based on the results of the data analysis conducted, it showed that the empowerment of important elements of community life as a source of social studies learning has not been done optimally by teachers. This could be seen from the learning planning developed, which seems to be lacking or even seems to integrate important elements of community life in learning planning. However, in the implementation of learning, some teachers have tried to impart learning by providing examples related to social problems that exist around the school environment.

The results of this study indicated that there were fundamental weaknesses in social studies learning. The fundamental weaknesses found were the important elements of community life that had not been empowered, and the utilization of symbols as media and learning resources in social studies learning. In fact, various important elements of community life are available in schools and the environment around the school which can be used as learning sources and learning media in training social skills for students. The sociocultural context surrounding the school is believed to be an important aspect that needs to be utilized and strengthened by the school to achieve school education goals, especially in the development of student character values.

\section{B. Discussion}

Based on the results of this research, it cannot be denied that education in schools cannot be separated from the influence of the socio-cultural context of the community that surrounds it. In this case, it can be seen that education is basically a socio-cultural process. Meaning that education in its efforts to shape behavior, impart knowledge, thought processes, values, learning methods, essential cognitive and social skills, and truth values will also be determined by how the community views the world and its values (society's prevailing world, view and values) [1,9].

Furthermore, it can be argued that the relative benefits of special goals and educative means are rooted in the social, cultural, political, and economic context in which people learn and in which educational institutions function. This seems inseparable from the viewpoint of functional structuralism, that in reality the function of school education is preparing the younger generation to have a system of language, knowledge, values, and attitudes, and skills needed in implementing the functions in society, including in the family. This is where the components of the school community (principals, teachers, and students) reconstruct critically to reproduce the image of a more democratic modern life providing a balance in provisioning the rights life socially, politically, culturally and economically between the local interests of the Balinese people, national interests, and the interests of the global community $[1,2]$.

Community empowerment as a learning resource is a very important thing to implement. This is because schools are not the only means for implementing the educational process, and formal education is not the only place where students learn to develop life skills. Community and workplace environment can also be used as a means for education and learning process to develop the skills needed to live in society. Learning by utilizing the essential elements of life in society would be more meaningful because it is not merely learning about formal knowledge that has been verified. Meaningful learning can also occur through participatory learning with the principle of learning by doing in the workplace to produce relevant life skills that are needed to live to society $[5,10]$.

It is said that because students can directly construct and develop social, cultural, and religious values in real social life practices in the environment that surrounds the existence of schools, as well as develop social skills that are needed by students in the life of society, nation and state. This is called school education based on real-world experience. Therefore, schools need to accommodate, adapt, and develop interests that must be the orientation of the values and actions of all school members and communities, both the level of local community interests, the level of national interest, and the level of global importance $[6,11,12]$.

\section{CONCLUSION}

There are various important elements of community life surround schools in the context of socio-culture, politics, economy, religion, ideology, and the views or values that live in society. The entire social, political, cultural, and economic context surrounding the existence of SMP/MTs in Singaraja City and other places in Buleleng Regency can be empowered as a medium and source of social studies learning.

There are fundamental weaknesses in social studies learning at SMP Lab. Undiksha, namely the important elements of community life have not been empowered, and the use of symbols as media and learning resources in social studies learning causing the social studies learning less powerful.

Obtaining optimal learning outcomes, social studies learning need to be developed in a powerful, in the sense of challenging, value-based, meaningful, and integrated. For this reason, teachers need to utilize various learning resources in social studies learning, especially learning sources in the community, and not only use textbooks as the only learning resource.

\section{REFERENCES}

[1] Y. Pai, Cultural Foundations of Education. New York: Macmillan Publishing Company, 1990.

[2] Sukadi, Pendidikan IPS sebagai Rekonstruksi Pengalaman Budaya berbasis Idiologi Tri Hita Karana pada SMU Negeri 1 UbudGianyar Bali. Bandung: Sekolah Pascasarjana UPI, 2006.

[3] Widja, Continuity and Change in Balinese Society: An Example from Modern Schooling. Indonesia Circle, No. 54 Mar. 91, 1991.

[4] S.A. Muchtar, Epistimologi Pendidikan Ilmu Pengetahuan Sosial. Bandung: Gelar Pustaka Mandiri, 2001.

[5] J. Jarolimek and Foster, 1989. Social Studies in Elementary Education. New York-London: Macmillan Publishing Company and Collier Macmillan Publishers. 
[6] M.N. Somantri, Menggagas Pembaharuan Pendidikan IPS. Bandung: UPI dan Rosda karya, 2001.

[7] U.S. Winataputra, Jati diri Pendidikan Kewarganegaraan sebagai Wahana Sistemik Pendidikan Demokrasi (Suatu Kajian Konseptual dalam Konteks Pendidikan IPS). Bandung: Universitas Pendidikan Indonesia, 2001.

[8] W. Kertih, Pegembangan Pembelajaran IPS Terpadu Berbasis Kearifan Lokal pada SMP di Provinsi Bali. Bali: Laporan Penelitian, Undiksha, 2007.
[9] Subagia, "Balinese Indigenous Worldview and Its Role in The Reforms of Science Education in Bali," Majalah Ilmiah Aneka Widya, vol XXXIII, pp. 71-81, 2000.

[10] W.B. Ragan and J.D. Mc. Aulay, Social Studies for Today's Children USA: Appleton-Century-Croft. Meredith Pub, 1964.

[11] G.M. Schuncke, Elementary Social Studies; Knowing, Doing, Caring. USA: MacMillan Pub.Co, 1988

[12] N. Supratna, and P. Waterworth, "Tantangan dalam Kurikulum IPS," Mimbar Pendidikan, Jurnal Pendidikan No. 2 Tahun XVI, pp. 31-37, 1997. 